\title{
Laser Processing of Thin Films for Photovoltaic Applications
}

\author{
Aart SCHOONDERBEEK ${ }^{* 1}$, Viktor SCHÜTZ ${ }^{* 1}$, Oliver HAUPT ${ }^{* 1}$, and Uwe STUTE ${ }^{* 1}$ \\ ${ }^{* 1}$ Laser Zentrum Hannover e.V., Hollerithallee 8, D-30419 Hannover, Germany, www.lzh.de \\ E-mail: a.schoonderbeek@lzh.de
}

\begin{abstract}
This paper discusses the structuring of several thin film materials used for solar cells, e.g. $\mathrm{SiN}_{\mathrm{x}}$, $\mathrm{SiO}_{2}$ and Transparent Conductive Oxides (TCOs). The focus of the experiments is to obtain an optimal edge quality without damaging the substrate below the structured region. Two important laser parameters are wavelength and pulse duration which determine the absorption of the laser radiation in the processed material and the extent of heat influence on the surrounding material. Processing with several wavelengths (e.g. $532 \mathrm{~nm}$ and $1064 \mathrm{~nm}$ ) and pulse durations especially in the pico- and nanosecond range is studied. The results obtained with the different laser parameters are compared by considering ablation threshold, debris, and damage due to heat conduction. The quality of laser processing is determined by optical and scanning electron microscopy. Results from the structuring of TCOs and organic layers are acquired with different laser types. Additionally, comparisons are made regarding the achievable structuring quality for mass production, relevant speeds around $1 \mathrm{~m} / \mathrm{s}$ for thin films and 1-2 seconds processing time for wafer based cells.

DOI:10.2961/jlmn.2010.03.0013
\end{abstract}

Keywords: photovoltaics, TCO, picosecond, nanosecond, laser structuring

\section{Introduction}

During the last years, research \& development (R\&D) activities in the field of photovoltaics have grown enormously. For many new concepts, like thin film modules, organic solar cells, and also new wafer based cell designs, conversion efficiencies increase constantly. For a successful market expansion, efficient and durable products at low costs are necessary. To realize this, laser structuring of thin films is of high importance for all the mentioned types of solar cells. To develop the required low-cost production technology, further R\&D in this field is still necessary. For new wafer based cell designs, the structuring of etching masks or dielectric layers without or with minimal damaging of the underlying material must be performed [1]. For thin film solar cells, structuring of several layer materials is used for the monolithic serial connection of cells in a module $[2,3]$. Laser ablation is already used for several processes in the photovoltaic industry but great challenges to improve quality, to increase processing speed, and to process new material combinations still remain.

For photovoltaic applications there are many structuring tasks where either a conductive connection between two layers or an electrical isolation in a conductive layer has to be realized. This is schematically shown in Figure 1 Such structures can be obtained in several ways. One possibility is to structure inherently when applying the layer, e.g. by using a mask for vapour deposition or by printing. Another method is structuring the layer by removing material after it is applied. A commonly used method for silicon-based electronics is the removal of layers by selective wet-chemical etching (lithography). A suitable alternative, or complementary technology, is laser structuring. Laser structuring is already in use in the mass production of several products, e.g. silicon based thin film solar modules [2].

This paper describes recent developments in the laser structuring of thin films, concentrating on materials which are predominantly transparent at industrially relevant laser wavelengths. To remove these layers, sufficient absorption of the laser radiation by the material is necessary. This is studied using a nanosecond pulse duration laser (ns-laser), a sub-nanosecond laser (sub-ns-laser), a picosecond laser (ps-laser) and, for $\mathrm{SiN}_{\mathrm{x}}$, a femtosecond laser (fs-laser). For several materials the best results are obtained using a pslaser, while for other materials good results are also obtained with ns-lasers and/or with sub-ns-lasers. The advantage of the ns- and sub-ns-laser is the low investment cost compared with fs- or ps-lasers. A goal of this work is to validate the industrial relevance of the material removal processes, for which cost is an important factor. This paper intends to provide an overview of the optimal results that can be achieved regarding the laser processing of various materials using currently available laser sources.

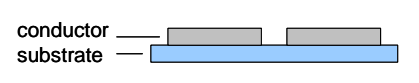

Fig. 1a Layout (cross-section) with a structured conducting layer to obtain an electrical isolation between two regions.

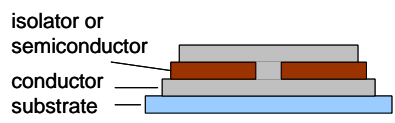

Fig. 1b Layout (cross-section) with a structured isolator or semi-conductor to obtain an electrical connection.

For practical applications, an economically feasible speed and reproducibility are necessary. Currently available laser sources have typical repetition rates between $50 \mathrm{kHz}$ and $500 \mathrm{kHz}$ and average powers up to $50 \mathrm{~W}$. With these repetition rates, line structuring speeds from $1 \mathrm{~m} / \mathrm{s}$ up to several $\mathrm{m} / \mathrm{s}$ for typical focus diameters in the range of $10 \mu \mathrm{m}$ up to $50 \mu \mathrm{m}$ are possible. A solution for process parallelization is shown using a Diffractive Optical Element (DOE) which makes efficient use of the available laser power.

\section{Experimental setup}

The lasers used for the experiments are listed in Table 1. The most important parameters of a laser source, the wave- 
length and pulse duration, are either fixed or adjustable only in a very small range. Thus, for the parameter variation, several laser sources are used.

Tab. 1 Laser sources for the experiments ( ${ }^{*}$ calculated [4]).

\begin{tabular}{cccc}
\hline laser & $\begin{array}{c}\text { wavelength } \\
\lambda[\mathrm{nm}]\end{array}$ & $\begin{array}{c}\text { pulse duration } \\
\mathrm{t}_{\mathrm{p}}\end{array}$ & $\begin{array}{c}\text { measured focus } \\
\text { diameter }\left(1 / \mathrm{e}^{2}\right)[\mu \mathrm{m}]\end{array}$ \\
\hline 1 & 515 & $7 \mathrm{ps}$ & 23 \\
2 & 1030 & $7 \mathrm{ps}$ & 47 \\
3 & 532 & $600 \mathrm{ps}$ & 33 \\
4 & 1064 & $30 \mathrm{~ns}$ & 77 \\
5 & 532 & $10 \mathrm{~ns}$ & 50 \\
6 & 1030 & $320 \mathrm{fs}$ & $80^{*}$ \\
\hline
\end{tabular}

The setup is similar for all performed experiments. Basically, the beam exiting the laser source first passes through a beam expander and is subsequently led into a galvo scanner to enable positioning of the beam onto the sample. An f-theta objective is used to focus the laser beam. The $1 / \mathrm{e}^{2}$ focus diameter is measured (Table 1 ), respectively calculated for laser 6 [4]. For the experiments a beam with Gaussian power density distribution is used.

The materials used in the experiments are listed in Table 2. The transmittances of the layers on transparent substrates are shown for the wavelength range from $300 \mathrm{~nm}$ up to $1100 \mathrm{~nm}$ (Figure 2). This is determined by subtracting the measured transmission of the substrate with layer from that of the substrate alone. Accordingly, differences in the reflection of the layers are neglected. These transmissions give an indication about the laser radiation absorption at $\sim 300 \mathrm{~K}$ with lower power densities than used for laser processing. Especially when increasing laser power density with respect to shorter pulse durations (e.g. fs and ps), nonlinear absorption has to be taken into account and there is an accordingly lower penetration depth of the laser radiation into the material. Furthermore, $\mathrm{Si}$, TCOs and PEDOT:PSS are semiconductors. Accordingly, generation of free charge carriers due to the laser radiation decreases the transmission and the optical penetration depth.

Tab. 2 Materials used in the experiments.

\begin{tabular}{llll}
\hline material & substrate & abbreviation & $\begin{array}{l}\text { typical } \\
\text { thicknesses }\end{array}$ \\
\hline silicon-dioxide & $\mathrm{Si}$ & $\mathrm{SiO}_{2}$ & $200 \mathrm{~nm}$ \\
silicon-nitride & $\mathrm{Si}$ & $\mathrm{SiN}_{\mathrm{x}}$ & $75 \mathrm{~nm}$ \\
indium tin oxide (TCO) & Glass & $\mathrm{ITO}$ & $125 \mathrm{~nm}$ \\
zinc oxide (TCO) & Glass & $\mathrm{ZnO}$ & $\approx 1 \mu \mathrm{m}$ \\
tin dioxide (TCO) & Glass & $\mathrm{SnO}_{2}$ & $\approx 1 \mu \mathrm{m}$ \\
$\begin{array}{l}\text { Poly(3,4- } \\
\text { thylenedioxythiophene)- } \\
\text { poly(styrenesulfonate) }\end{array}$ & FET- & PEDOT:PSS & $\approx 100 \mathrm{~nm}$ \\
\hline
\end{tabular}

In the experiments material is removed with both single spots and line scribing by overlapping spots with a single pass of the laser beam over the sample.

The experimental setup is extended for process parallelization experiments with a 7-spot DOE. This element is inserted into the beam path in front of the galvo scanner. A DOE has losses due to absorption in the optical material, reflection, and also unwanted diffraction of laser radiation into higher orders. Especially variations in uniformity of the individual spots must be considered for a comparison of laser processing with a single spot to laser processing with multi spot elements. For this comparison the measured power for the seven spots of the DOE is seven times the measured power for the single spot. For the power meas- urement with the DOE a slit power measurement technique is applied. Here a slit is placed in the focal plane to block higher (unwanted) orders obtained with the DOE. This method ensures a correct power measurement.

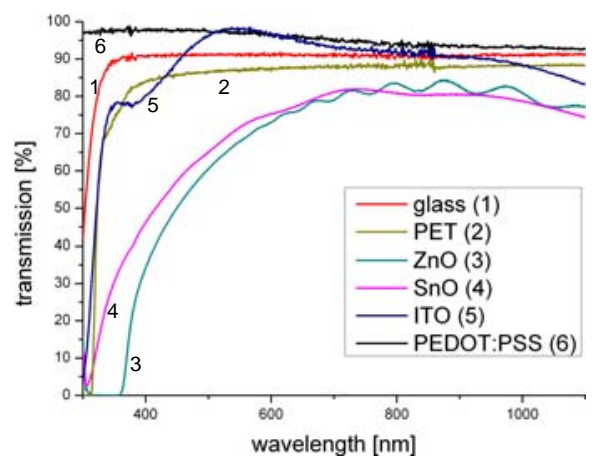

Fig. 2 Measured transmission of layers on transparent substrates.

\section{Results and discussion}

In Table 3 an overview of the best results obtained, determined by optical microscopy, with corresponding parameters is given. Due to its high transparency PEDOT:PSS is not removed with lasers 4 and 5 in the tested parameter range. In Table $3, H_{p}$ is the fluence and $s$ the spot-to-spot distance. Results are chosen where no strong variations in the ablated spot diameter are visible, which would occur when too close to the ablation threshold. Visible spot diameter variations (Table 3) are due to parameter variations like layer thickness, pulse-to-pulse energy stability etc.

The results of the experiments are presented in a convenient way in Table 4. The Volumetric Energy Density (VED), $\varepsilon$, in $\left[\mathrm{J} / \mathrm{mm}^{3}\right]$ is calculated according:

$$
\varepsilon=\frac{4 \cdot E_{p}}{\pi \cdot d_{f o c} \cdot s \cdot \delta}
$$

in which $E_{p}$ is the pulse energy, $d_{f o c}$ the focus diameter $\left(1 / \mathrm{e}^{2}\right), s$ the spot-to-spot distance, and $\delta$ the layer thickness. For line scribing the used spot-to-spot distance $s$ is smaller than the ablated spot diameter $d_{f}\left(s \leq d_{f}\right)$.

\section{Crystalline solar cells $\left(\mathrm{SiO}_{2}\right.$ and $\left.\mathrm{SiN}_{\mathrm{x}}\right)$}

$\mathrm{SiO}_{2}$ and $\mathrm{SiN}_{\mathrm{x}}$ demonstrate similar behavior during laser processing. $\mathrm{SiO}_{2}$ has a high transparency in the investigated spectral range. The absorption coefficient for $\mathrm{SiO}_{2}$ is smaller than $100 \mathrm{~m}^{-1}$ at $300 \mathrm{~K}[5,6]$. Although the transparency of $\mathrm{SiN}_{\mathrm{x}}$ depends on its composition, the layers used for solar cells have a similar transparency as $\mathrm{SiO}_{2}$ [7]. The laser radiation is mainly absorbed by the underlying silicon at fluences as used in the experiments. The $\mathrm{Si}$ is molten and evaporated; consequently the thin layer is lifted off. The influence of the wavelength on the amount of thermally damaged silicon (e.g. molten and re-solidified) seems to be minimal but not negligible for all tested lasers. While this is known for ps-lasers, it is also known that for the longer ns-pulses the depth of the crystal damage in the silicon increases at higher laser wavelengths due to the higher optical penetration depth $[1,8]$. Furthermore, comparing "long" ns-pulses with "short" ps-pulses a thicker Si layer is influenced due to heat conduction. Consequently, for the ps-laser a thinner layer of molten Si results in a smoother surface and a smaller zone with crystal damage. A minimal or absent zone with crystal damage is advantageous for 
applications in solar cell production because crystal damage shortens the carrier lifetime and thus decreases the effi- ciency of the solar cell $[9,10]$. 
Tab. 3 Optimal results experimentally obtained. Results are chosen where no strong variations in the $50 \mu \mathrm{m}$ ablated spot diameter are visible, which would occur when too close to the ablation threshold.

\begin{tabular}{|c|c|c|c|c|c|c|c|}
\hline $\begin{array}{c}\text { pulse } \\
\text { duration }\end{array}$ & parameter & $\mathrm{SiO}_{2}$ & $\mathrm{SiN}_{\mathrm{x}}$ & PEDOT:PSS & $\mathrm{ZnO}$ & $\mathrm{SnO}_{2}$ & ITO \\
\hline & $\begin{array}{l}\text { laser } 1 \\
\lambda=515 \mathrm{~nm} \\
t_{p}=7 \mathrm{ps} \\
\text { irr. side: layer }\end{array}$ & $8:$ & & & & & \\
\hline ర్̈ & $\begin{array}{l}H_{p}\left[\mathrm{~mJ} / \mathrm{cm}^{2}\right]: \\
s[\mu \mathrm{m}]:\end{array}$ & $\begin{array}{l}230 \\
12\end{array}$ & $\begin{array}{l}280 \\
12\end{array}$ & $\begin{array}{l}280 \\
12\end{array}$ & $\begin{array}{l}2090 \\
10\end{array}$ & $\begin{array}{l}980 \\
21\end{array}$ & $\begin{array}{l}420 \\
12\end{array}$ \\
\hline.$\frac{0}{2}$ & $\begin{array}{l}\text { laser } 2 \\
\lambda=1030 \mathrm{~nm} \\
t_{p}=7 \mathrm{ps} \\
\text { irr. side: layer }\end{array}$ & & & 1 & & & \\
\hline & $\begin{array}{l}H_{p}\left[\mathrm{~mJ} / \mathrm{cm}^{2}\right] \\
s[\mu \mathrm{m}]\end{array}$ & $\begin{array}{l}290 \\
19\end{array}$ & $\begin{array}{l}470 \\
23\end{array}$ & $\begin{array}{l}470 \\
23\end{array}$ & $\begin{array}{l}700 \\
16\end{array}$ & $\begin{array}{l}580 \\
19\end{array}$ & $\begin{array}{l}290 \\
19 \\
\end{array}$ \\
\hline $\begin{array}{l}\text { T्र } \\
0 \\
0 \\
0\end{array}$ & $\begin{array}{l}\text { laser } 3 \\
\lambda=532 \mathrm{~nm} \\
t_{p}=600 \mathrm{ps} \\
\text { irr. side: layer }\end{array}$ & & & & & & \\
\hline$\stackrel{1}{\vec{n}}$ & $\begin{array}{l}H_{p}\left[\mathrm{~mJ} / \mathrm{cm}^{2}\right] \\
s[\mu \mathrm{m}]\end{array}$ & $\begin{array}{l}810 \\
20\end{array}$ & $\begin{array}{l}290 \\
20 \\
\end{array}$ & $\begin{array}{l}700 \\
30 \\
\end{array}$ & $\begin{array}{l}1360 \\
50\end{array}$ & $\begin{array}{l}1460 \\
26\end{array}$ & $\begin{array}{l}920 \\
33 \\
\end{array}$ \\
\hline \multirow{8}{*}{ 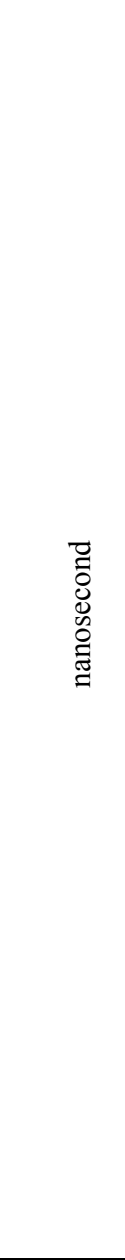 } & $\begin{array}{l}\text { laser } 4 \\
\lambda=1064 \mathrm{~nm} \\
t_{p}=30 \mathrm{~ns} \\
\text { irr. side: layer }\end{array}$ & & & $\begin{array}{l}\text { no } \\
\text { optimum } \\
\text { found }\end{array}$ & & & \\
\hline & $\begin{array}{l}H_{p}\left[\mathrm{~mJ} / \mathrm{cm}^{2}\right] \\
s[\mu \mathrm{m}]\end{array}$ & $\begin{array}{l}500 \\
23\end{array}$ & $\begin{array}{l}2100 \\
31 \\
\end{array}$ & & $\begin{array}{l}3020 \\
31\end{array}$ & $\begin{array}{l}3000 \\
30\end{array}$ & $\begin{array}{l}1260 \\
31\end{array}$ \\
\hline & $\begin{array}{l}\text { laser } 4 \\
\lambda=1064 \mathrm{~nm} \\
t_{p}=30 \mathrm{~ns} \\
\text { irr. side: glass }\end{array}$ & $\begin{array}{l}\text { not } \\
\text { irradiated } \\
\text { through } \\
\text { substrate }\end{array}$ & $\begin{array}{l}\text { not } \\
\text { irradiated } \\
\text { through } \\
\text { substrate }\end{array}$ & $\begin{array}{l}\text { no } \\
\text { optimum } \\
\text { found }\end{array}$ & & & \\
\hline & $\begin{array}{l}H_{p}\left[\mathrm{~mJ} / \mathrm{cm}^{2}\right] \\
s[\mu \mathrm{m}]\end{array}$ & & & & $\begin{array}{l}3020 \\
31\end{array}$ & $\begin{array}{l}2000 \\
30\end{array}$ & $\begin{array}{l}1510 \\
31\end{array}$ \\
\hline & $\begin{array}{l}\text { laser } 5 \\
\lambda=532 \mathrm{~nm} \\
t_{p}=10 \mathrm{~ns} \\
\text { irr. side: layer }\end{array}$ & & 8 & $\begin{array}{l}\text { no } \\
\text { optimum } \\
\text { found }\end{array}$ & & & \\
\hline & $\begin{array}{l}H_{p}\left[\mathrm{~mJ} / \mathrm{cm}^{2}\right] \\
s[\mu \mathrm{m}]\end{array}$ & $\begin{array}{l}1681 \\
25\end{array}$ & $\begin{array}{l}255 \\
7 \\
\end{array}$ & & $\begin{array}{l}5022 \\
14\end{array}$ & $\begin{array}{l}1120 \\
21\end{array}$ & $\begin{array}{l}917 \\
14\end{array}$ \\
\hline & $\begin{array}{l}\text { laser } 5 \\
\lambda=532 \mathrm{~nm} \\
t_{p}=10 \mathrm{~ns} \\
\text { irr. side: glass }\end{array}$ & $\begin{array}{l}\text { not } \\
\text { irradiated } \\
\text { through } \\
\text { substrate }\end{array}$ & $\begin{array}{l}\text { not } \\
\text { irradiated } \\
\text { through } \\
\text { substrate }\end{array}$ & $\begin{array}{l}\text { no } \\
\text { optimum } \\
\text { found }\end{array}$ & & & \\
\hline & $\begin{array}{l}H_{p}\left[\mathrm{~mJ} / \mathrm{cm}^{2}\right] \\
s[\mu \mathrm{m}]\end{array}$ & & & & $\begin{array}{l}1528 \\
14\end{array}$ & $\begin{array}{l}474 \\
14\end{array}$ & $\begin{array}{l}1986 \\
21\end{array}$ \\
\hline
\end{tabular}


Tab. 4 A tentative assessment results; colored dots represent the quality of the processing in a traffic light scheme. Green is good, red is not good and yellow is not optimal.

\begin{tabular}{|c|c|c|c|c|c|c|c|}
\hline $\begin{array}{c}\text { pulse } \\
\text { duration }\end{array}$ & parameter & $\mathrm{SiO}_{2}$ & $\mathrm{SiN}_{\mathrm{x}}$ & $\begin{array}{l}\text { PEDOT } \\
: \text { PSS }\end{array}$ & $\mathrm{ZnO}$ & $\mathrm{SnO}_{2}$ & ITO \\
\hline \multirow{4}{*}{$\stackrel{2}{2}$} & $\begin{array}{l}\text { laser } 1,515 \mathrm{~nm}, 7 \mathrm{ps} \\
\text { irr. side: layer }\end{array}$ & O & O & O & 0 & 0 & 0 \\
\hline & $\varepsilon\left[\mathrm{J} / \mathrm{mm}^{3}\right]$ & 22 & 75 & 55 & 49 & 11 & 66 \\
\hline & $\begin{array}{l}\text { laser } 2,1030 \mathrm{~nm}, 7 \mathrm{ps} \\
\text { irr. side: layer }\end{array}$ & O & ○ & O & O & O & 0 \\
\hline & $\varepsilon\left[\mathrm{J} / \mathrm{mm}^{3}\right]$ & 36 & 128 & 96 & 20 & 14 & 57 \\
\hline \multirow{2}{*}{$\overbrace{\tilde{n}}^{1} \tilde{z}$} & $\begin{array}{l}\text { laser 3, } 532 \mathrm{~nm}, 600 \mathrm{ps} \\
\text { irr. side: layer }\end{array}$ & O & 0 & ○ & O & 0 & 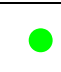 \\
\hline & $\varepsilon\left[\mathrm{J} / \mathrm{mm}^{3}\right]$ & 67 & 64 & 77 & 9 & 19 & 74 \\
\hline \multirow{8}{*}{$\cong$} & $\begin{array}{l}\text { laser } 4,1064 \mathrm{~nm}, 30 \mathrm{~ns} \\
\text { irr. side: layer }\end{array}$ & 0 & ○ & $X$ & 0 & ○ & O \\
\hline & $\varepsilon\left[\mathrm{J} / \mathrm{mm}^{3}\right]$ & 84 & 696 & - & 75 & 77 & 250 \\
\hline & $\begin{array}{l}\text { laser } 4,1064 \mathrm{~nm}, 30 \mathrm{~ns} \\
\text { irr. side: glass }\end{array}$ & $X$ & $X$ & $X$ & $\bullet$ & O & 0 \\
\hline & $\varepsilon\left[\mathrm{J} / \mathrm{mm}^{3}\right]$ & - & - & & 75 & 51 & 300 \\
\hline & $\begin{array}{l}\text { laser } 5,532 \mathrm{~nm}, 10 \mathrm{~ns} \\
\text { irr. side: layer }\end{array}$ & 0 & O & X & ○ & O & 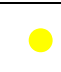 \\
\hline & $\varepsilon\left[\mathrm{J} / \mathrm{mm}^{3}\right]$ & 172 & 304 & - & 120 & 27 & 262 \\
\hline & $\begin{array}{l}\text { laser } 5,532 \mathrm{~nm}, 10 \mathrm{~ns} \\
\text { irr. side: glass }\end{array}$ & $X$ & $X$ & $X$ & O & O & 0 \\
\hline & $\varepsilon\left[\mathrm{J} / \mathrm{mm}^{3}\right]$ & - & - & - & 55 & 17 & 378 \\
\hline
\end{tabular}

Even shorter pulses than ps can be advantageous for removing these highly transparent layers. Presently, ps-lasers are established in industry. Due to strong progress in fs-laser development, fs-lasers are an option for photovoltaic applications in the near future. Laser processing of $\mathrm{SiN}_{\mathrm{x}}$ with fs pulses results in a sharp ablation edge quality (Figure 3). The high fluence and short pulse duration result
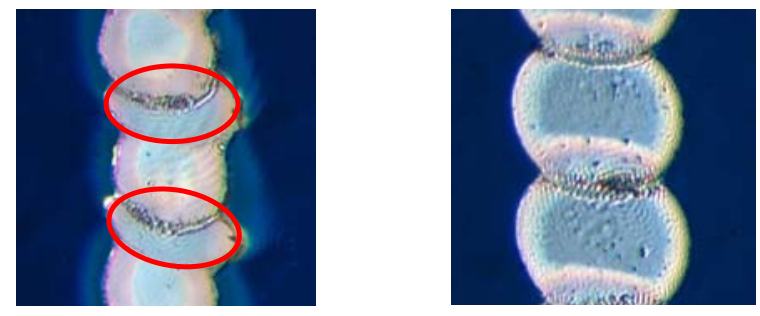

Fig. 3: left: removed $\mathrm{SiN}_{\mathrm{x}}$ layer (removed spot diameter approx. $18 \mu \mathrm{m})\left(\lambda=1030 \mathrm{~nm}, \mathrm{t}_{\mathrm{p}}=320 \mathrm{fs}, \mathrm{H}_{\mathrm{p}}=80 \mathrm{~mJ} / \mathrm{cm}^{2}, \varepsilon=43 \mathrm{~J} / \mathrm{mm}^{3}\right)$. Red oval marks spot overlap region. right: removed $\mathrm{SiN}_{\mathrm{x}}$ layer (removed spot diameter approx. $33 \mu \mathrm{m})\left(\lambda=1030 \mathrm{~nm}, \mathrm{t}_{\mathrm{p}}=7 \mathrm{ps}\right.$, $\left.\mathrm{H}_{\mathrm{p}}=470 \mathrm{~mJ} / \mathrm{cm}^{2}, \varepsilon=43 \mathrm{~J} / \mathrm{mm}^{3}\right)$.

in less thermal damage to the underlying silicon when compared to ps-pulses. This is due to higher (non-linear) optical absorption of the laser radiation by the layer itself. The peak power density is up to 7 times higher than in the experiments with the ps-lasers 1 and 2 . The surface of the silicon is smooth in contrast to the ripples on the silicon surface caused by the ps-laser of the same wavelength. This indicates melting and re-solidifying of the silicon during processing with the ps-laser and that more $\mathrm{SiN}_{\mathrm{x}}$ is removed directly and not as a lift off process with the fs-laser. Furthermore, for the fs-laser, the region between the spots is also partially removed due to an additional (second time) irradiation with a gaussian laser spot distribution of the previous irradiated area (Figure 3: red ovals). This behavior is not observed with ns- and sub-ns-lasers and is minimally observed for ps-laser (1 and 2).

The results obtained with the sub-ns-laser show less resolidified molten material, for both $\mathrm{SiO}_{2}$ and $\mathrm{SiN}_{\mathrm{x}}$, than with the ns-laser but more than with the ps-laser. Accordingly, layer removal of $\mathrm{SiO}_{2}$ and $\mathrm{SiN}_{\mathrm{x}}$ with the sub-ns-laser results in less thermally damaged silicon than obtained with the longer pulses of the ns-laser. The costs for the lasers are however similar.

\section{Thin film solar cells (TCO)}

ITO, $\mathrm{ZnO}$ and $\mathrm{SnO}_{2}$ are TCOs and demonstrate similar behavior during laser processing. Glass is used as substrate for these layers, and has a similar transparency to the TCO itself. Accordingly, the challenge is to remove the layer without damaging the glass. The results are first analyzed by optical microscopy (Table 3 ) but, in contrast to $\mathrm{SiO}_{2}$ and $\mathrm{SiN}_{\mathrm{x}}$, details are not clearly visible. Therefore further analysis with a Scanning Electron Microscope (SEM) is performed (Table 5). Principally, there are two ways to irradiate the sample; from the layer side and from the glass side [11]. Due to the high power densities of the ultrashort-pulse-lasers, damage to the glass substrate can occur easily and is observed for some of the tested materials in the experiments before the layer is removed. Damage to the glass is observed during the ns-laser processing of TCO, but only with $\mathrm{ZnO}$. Such damage however is avoided by processing through the glass. With the ps-laser (no. 2) the $\mathrm{ZnO}$ layer is removed, but small amounts of the layer material stay behind (Table 5). At higher fluences the glass substrate starts to become damaged. Removing the ITO layer with the ps-laser results in a clean surface without residue (Table 5). As mentioned, regarding the ns-laser, damage to the glass substrate is observed when removing the $\mathrm{ZnO}$ layer with irradiation from the layer side. However, the result obtained when irradiating from the glass side shows a clean substrate surface and smooth edges, as good or even better than obtained with the ps-laser. For ITO the difference in results obtained for the edge quality with the ns-laser seems to be independent of the choice of irradiation side. With the sub-ns- and ns-laser, irradiated from the layer side, the complete ITO thickness seems to be removed. However, some debris and/or residue are visible. With the ns-laser, irradiating from the substrate side, the substrate surface is cleaner. Removing the $\mathrm{SnO}_{2}$ layer with the ps- and sub-ns-laser, irradiating from the layer side shows a clean surface and smooth edges. Removing the $\mathrm{SnO}_{2}$ layer with the ns-laser, irradiating either from the layer or from the substrate side shows a clean surface and slightly re-solidified melt at the edges.

\section{Organic solar cells (PEDOT:PSS)}

PEDOT:PSS is highly transparent. With ns pulse duration the PEDOT:PSS is not removed, instead it is slightly molten. Using the ps-laser, PEDOT:PSS is removed completely (Table 3 ). Also the sub-ns pulses resulted in proper layer removal. Furthermore, the difference between the two ps-laser wavelengths is remarkable. The process window with respect to fluence, using $1030 \mathrm{~nm}$, is about two times larger than using $515 \mathrm{~nm}$. This process window is defined as the range between the fluence where proper layer removal is observed and the fluence at which damage of the PET-foil is observed. The observed effect indicates a higher absorption of the $515 \mathrm{~nm}$ wavelength radiation by the PETfoil. 


\section{Removal thresholds of $\mathrm{SiO}_{2}, \mathrm{SiN}_{\mathrm{x}}$ and ITO}

In this section, a method to quantify the qualitative results is presented. It is possible to calculate the specific removal thresholds by determining the removed spot diameter on different materials in analogy to Liu [4]. Relating the laser costs with the determined removal thresholds allows the most economic laser system for the desired application to be determined.

Tab. 5 SEM images

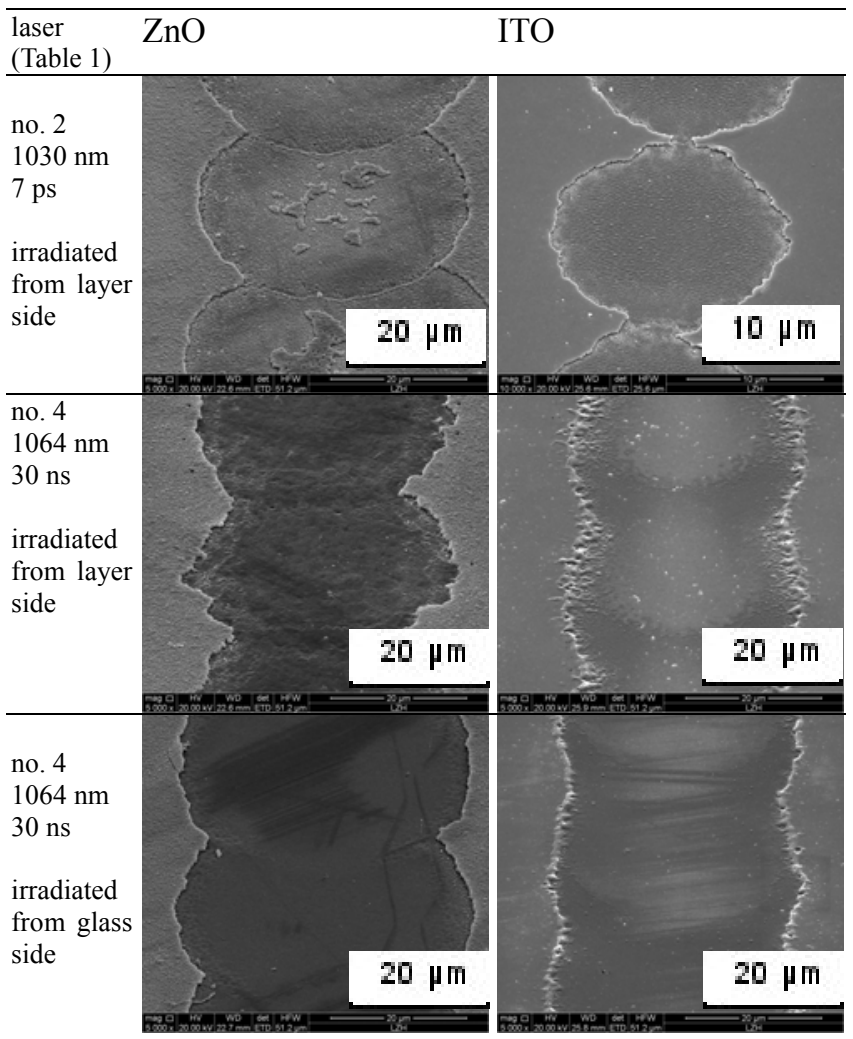

In the following the fluence thresholds for removing thin layers $\left(\mathrm{SiN}_{\mathrm{x}}, \mathrm{SiO}_{2}\right.$ on silicon and ITO on glass substrate) are compared. This is done for both single spot and multiple spots material removal. The thresholds are determined for $\mathrm{t}_{\mathrm{p}}=7 \mathrm{ps}$ at $\lambda=1030 \mathrm{~nm}$ and $515 \mathrm{~nm}$ for the mentioned three layer materials. In case of $\mathrm{SiN}_{\mathrm{x}}$ the threshold for $t_{p}=320 \mathrm{fs}$ at $\lambda=1030 \mathrm{~nm}$ is also determined. Spot-tospot distances resulting in isolated spots and up to $60 \%$ spot-to-spot overlap are used. In Figure 4 the diameter of the removed spot as a function of the fluence is shown for $\mathrm{SiO}_{2}$ and ITO at a laser wavelength of $\lambda=515 \mathrm{~nm}$. The intersection of the point fitted curves and the axis of abscissa quantifies the removal threshold of the thin layer. For the other materials, similar behavior and variance is found.

Figure 4 shows that the line width (ablated spot diameter) increases with increasing overlap, especially at higher fluences. This effect is also clearly observed for $\operatorname{SiN}_{\mathrm{x}}$. In contrast, the TCOs and here in particular ITO does not show this behavior in the examined regime. It is expected that in the ITO layer absorbed laser radiation results not only in vaporization and melting of the ITO, but also in the breaking out of particles. This happens especially on the edges where the fluence is relatively low due to the Gaussian fluence distribution. For this mechanism the influence of the overlap on the line width is minimal, while the thermal effects on the edge are minimal. For $\mathrm{SiO}_{2}$ and $\mathrm{SiN}_{\mathrm{x}}$ the removal takes place mainly by removing the underlying silicon, by melting and vaporization. Due to larger overlaps and subsequently larger heat accumulation at the edges, even for ps-pulses, an increasing line width for increasing overlap is expected.

The removal thresholds for $\mathrm{SiN}_{\mathrm{x}}, \mathrm{SiO}_{2}$ and ITO are listed in Table 6. The different standard deviations are due to varying surface roughness, variations in layer thickness and also inaccuracies in measurements at smaller spot diameters.

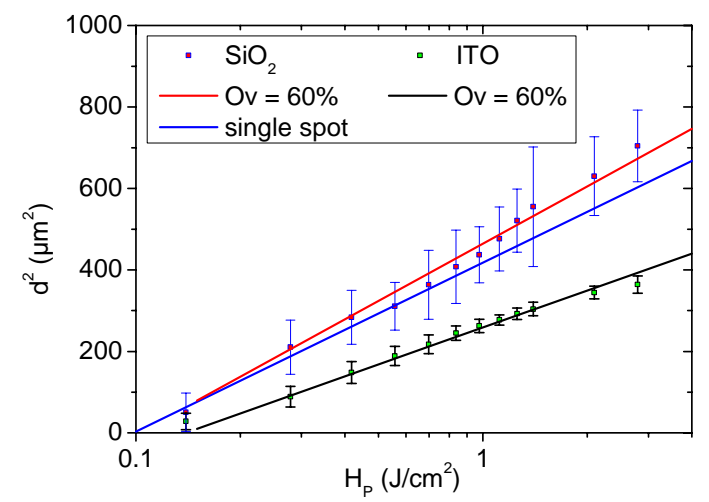

Fig. 4 Measured removed spot diameter at different fluences $\left(\lambda=515 \mathrm{~nm}, \mathrm{t}_{\mathrm{p}}=7 \mathrm{ps}\right)$. Lines: fitted curves at mentioned overlaps [4]. Boxes: for a better overview measured average removed spot diameters from single spot up to $60 \%$ overlap $(\mathrm{OV})$ are shown.

Tab. 6 Removal thresholds for thin layers

\begin{tabular}{llll}
\hline material & $\begin{array}{c}\text { laser } \\
\text { (Table 1) }\end{array}$ & $\begin{array}{c}\text { wavelength } \\
\lambda[\mathrm{nm}]\end{array}$ & $\begin{array}{l}\text { Threshold } \\
\mathrm{H}_{\text {Pth }}\left[\mathrm{J} / \mathrm{cm}^{2}\right]\end{array}$ \\
\hline $\mathrm{SiO}_{2}$ & 2 & 1030 & $0.124 \pm 0.025$ \\
& 1 & 515 & $0.112 \pm 0.013$ \\
$\mathrm{SiN}_{\mathrm{x}}$ & 6 & 1030 & $0.065 \pm 0.010$ \\
& 2 & 1030 & $0.089 \pm 0.006$ \\
& 1 & 515 & $0.055 \pm 0.012$ \\
$\mathrm{ITO}$ & 2 & 1030 & $0.165 \pm 0.034$ \\
& 1 & 515 & $0.138 \pm 0.021$ \\
\hline
\end{tabular}

According to Table 5 the determined threshold fluences are realized with a pulse energy, which is low compared to what is achievable with the used laser, especially for $\operatorname{SiN}_{\mathrm{x}}$.

\section{Efficiency gain by process parallelization}

Remarkable for the performed experiments is that only a small fraction of the laser power is used. With the available excess of laser power it is possible to parallelize the processes with a diffractive optical element (DOE) to increase the process speed for structuring thin layers [12]. For example, the optimal pulse energy for $\mathrm{SiN}_{\mathrm{x}}$ removal with laser 2 is $1.2 \mu \mathrm{J}$. The maximum pulse energy is $60 \mu \mathrm{J}$, so only about $2 \%$ of the available laser power is used. This indicates great potential for a more efficient use of energy. Therefore a beam splitting method to enable an optimal use of the laser power is evaluated, yielding an efficiency gain via process parallelization. The used laser setup is able to achieve fluences up to $H_{P}=6 \mathrm{~J} / \mathrm{cm}^{2}$ for $\lambda=1030 \mathrm{~nm}$ and $\mathrm{H}_{\mathrm{P}}=14 \mathrm{~J} / \mathrm{cm}^{2}$ for $\lambda=515 \mathrm{~nm}$. Process parallelization has been tested with $\mathrm{SiN}_{\mathrm{x}}$ and a 7 -spot DOE. The fluence of each spot of the DOE is the same as in the single spot experiments. Process parameters are chosen to achieve separated spots instead of lines. 
Important for obtaining uniform processing results is a consistent spatial power density distribution in the focus of each of the 7 spots. Directly measuring this with the required accuracy is impracticable. Therefore another method, using the measured ablated spot diameter, is used. Figure 5 shows the obtained ablated spot diameter distribution, normalized to the maximum. The distribution is independent of the applied laser parameters. The diameter spreading between the 7 spots is measurable $(\approx 4 \%)$ but so small that is not relevant for the described experiments, as seen in Table 6 where the lowest standard deviation is approx. 2 times larger. The optical efficiency of the used DOE is approx. $83 \%$.

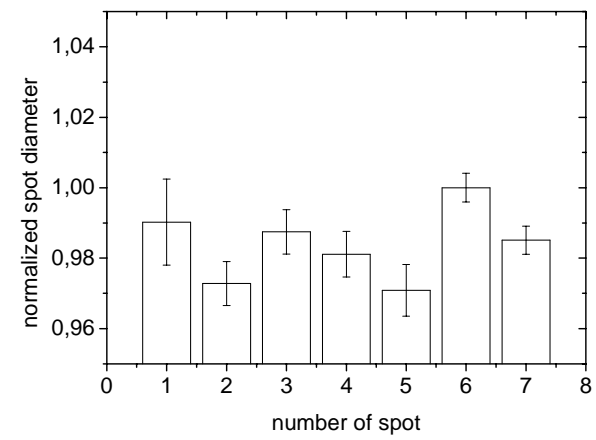

Fig. 5 Normalized spot diameter distribution for the 7-spot DOE.

In Figure 6 the spot diameter versus fluence is shown for a single spot and a 7-spot DOE. The differences in spot sizes at specific fluences are negligibly small.

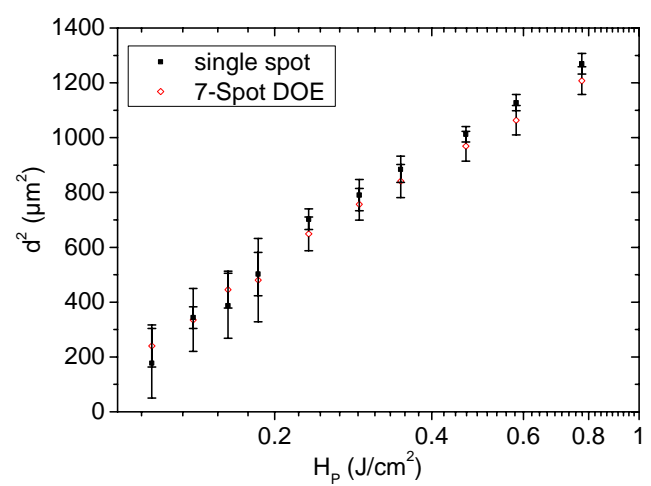

Fig. 6 Measured removed spot diameter at different fluences on $\operatorname{SiN}_{\mathrm{x}}\left(\lambda=1030 \mathrm{~nm}, \mathrm{t}_{\mathrm{p}}=7 \mathrm{ps}\right)$.

The threshold for removing $\mathrm{SiN}_{\mathrm{x}}$ with a DOE is similar to when using single pulses. This shows that the quality of commercially available DOEs for beam splitting is high enough to achieve equal processing results with each single spot. Equal results are required to realize process parallelization with optimal use of the available laser power and thus obtaining minimal cost and high processing speed.

\section{Summary and Outlook}

Thin films are removed successfully by laser processing, nevertheless different dominant ablation mechanisms for the glass and silicon substrates are observed. According to the application's demands and for the various layer material combinations, a wide range of laser parameters are evaluated.

Layers on Si-wafers must be machined from the top side and ablation of silicon must be considered in the process. For removing $\mathrm{SiO}_{2}$ and $\mathrm{SiN}_{\mathrm{x}}$ melting and evaporating silicon causes the layer lift off. Accordingly, the amount of molten and re-solidified $\mathrm{Si}$ increases with increasing pulse duration. With a pulse duration of $320 \mathrm{fs}, \mathrm{SiN}_{\mathrm{x}}$ could even be directly ablated without using $\mathrm{Si}$ evaporation to lift off the layer.

In analogy to Si-wafers, removing the PEDOT:PSS on organic foils must be carried out from the top side and subns- or ps-pulses are necessary due to the high transparency of the layer material. The best quality TCO removal is obtained with the ps- and sub-ns-lasers, but almost similar and for most applications sufficient quality is observed with ns-lasers.

In contrast to silicon, glass has low absorption for the used wavelength and can be machined from both sides. Generally, with ultra-short pulses (fs-, ps-laser) the layer can be removed effectively. However, high intensities limit the process window due to high order absorption which may cause damage to the substrate. With the ns-lasers, damage to the substrate is less problematic. The removal of the layer itself is less effective and show more thermal effects than with the ultra-short pulses. With the sub-ns-laser a good compromise is found with respect to quality, while the investment remains similar to that for ns-lasers.

Since low fluences are required to remove thin layers, smart optical systems enable the use of full laser power. It is shown that the use of the available laser power can be enhanced and thus can reduce costs at high throughput by using process parallelization with DOE.

In this paper a brief overview of the processing of various materials is given. For an industrial application of the laser processing technology a further optimization for individual materials is necessary, especially with respect to reproducibility, e.g. regarding the influence of deviations such as changes in layer thicknesses, composition of the material etc. For specific applications further research must be done to investigate the results obtained with the several laser sources, in terms of electrical properties after processing, and structural changes due to thermal influences etc.

\section{Acknowledgements}

The authors would like to thank Innolight $\mathrm{GmbH}$ and Amplitude Systems/ALPhANOV for the opportunity to use their lasers in the application laboratories. Furthermore, the authors would like to thank Dr. Hoppe and Mr. Bärenklau from the TU-Ilmenau for providing the PEDOT:PSSsamples.

\section{References}

1. S. Hermann, T. Neubert, B Wolpensinger, N.-P. Harder, R. Brendel, S. Massa, U. Stute: Proceedings $23^{\text {th }}$ EUPVSEC, (2008) p.1204

2. S. Haas, A. Gordijn, H. Stiebig: Progr. Photovolt: Res. Appl., 16, (2008) p.195

3. R. Rösch, B. Muhsin, M. Bärenklau, A. Schoonderbeek, G. Gobsch, L. Richter, R. Kling, D. Teckhaus, H. Hoppe: Proceedings $24^{\text {th }}$ EUPVSEC, (2009) p.672

4. J.M. Liu: Opt. Lett., 7, (1982) p.196

5. D. Bäuerle: "Laser Processing and Chemistry", $3^{\text {rd }}$ ed., Springer, (2000)

6. S. Hermann, N.-P. Harder, R. Brendel, D. Herzog, H. Haferkamp: Appl. Phys. A: Mater, Sci, Process, 99, (2010) p.151 
7. J. Schmidt, M. Kerr: Sol. Energy Mater. Sol. Cells, 65, (2001) p.585

8. P. Engelhart, R. Grischke, S. Eidelloth, R. Meyer, A. Schoonderbeek, U. Stute, A. Ostendorf, R. Brendel: Proceedings ICALEO, (2006) p.218

9. A. Knorz, A. Grohe, C. Harmel, R. Preu, J. Luther: Proceedings $22^{\text {nd }}$ EUPVSEC, (2007) p. 1488

10. P. Engelhart, S. Hermann, T. Neubert, H. Plagwitz, R. Grischke, R. Meyer, U. Klug, A. Schoonderbeek, U. Stute, R. Brendel: Progr. Photovolt: Res. Appl., 15, (2007) p.521

11. J. Bovatsek, A. Tamhankar, R. Patel, N. Bulgakova, J. Bonse: Thin Sol. Films, 518, (2010) p.2897

12. F. Siegel, O. Haupt, R. Kling: Proceedings PICALO, (2010) M604

(Received: June 21 , 2010, Accepted: November 16, 2010) 